\title{
Cluster Frontline Demonstrations Impact on Productivity of Soybean in Dewas District of Malwa Plateau
}

\author{
K. S. Bhargav ${ }^{*}$, Nishith Gupta, Ankita Pandey and A. K. Dixit \\ R.V.S.K.V.V. Krishi Vigyan Kendra, Dewas, Madhya Pradesh, India \\ *Corresponding author
}

\section{A B S T R A C T}

\section{Keywords}

Soybean, JS 9560, Raised bed and FIRBS, etc

Article Info

Accepted:

08 December 2020

Available Online:

10 January 2021
Cluster Front line demonstrations on soybean variety JS 9560 were organized at 200 farmers field consecutively for two years in kharif seasons of 2016 and 2017 in many adopted villages of dewas district by Krishi Vigyan Kendra, Dewas. The package of improved practices demonstrated, which included a new variety JS 95-60, integrated nutrient management (@ 20:60:20:20:: N:P2O5:K2O:S kg/ha + rhizobium @ 5g/kg seed + PSB @ $5 \mathrm{~g} / \mathrm{kg}$ of seed), integrated pest management (deep ploughing during April + seed treatment with Trichoderma virdae@5g/kg seed + trizophos@ $750 \mathrm{ml} / \mathrm{ha}$ ) and sowing on ridge and furrow method and Furrow irrigated raised bed method led to higher seed yields (15.29 to 18.29 qt per ha with an average $16.79 \mathrm{qt} / \mathrm{ha}$ ) as compared to farmers' practice (12.38 to $14.68 \mathrm{qt}$ per ha with an (average $13.53 \mathrm{qt} / \mathrm{ha}$ ). This increase over farmers' practice ranged from 24.59 and 14.29 per cent during kharif 2016 and 2017 respectively. The adoption of improved package of practices, on an average, also resulted in increased gross (by $25.03 \%$ ) and net (by $96 \%$ ) returns and benefit cost ratio (by $21.7 \%$ ) as compared to farmers' practice.

\section{Introduction}

Soybean [Glycine max (L.) Merrill] is an important crop with high protein $(40 \%)$ and oil content $(20 \%)$. It is also used to make soya milk, tofu, soynuts, etc. It is a legume that grows in tropical, subtropical and temperate climate. It has great potential as a kharif oilseed and has emerged as an important commercial oilseed in Madhya Pradesh. Soybean is established as major rainy season in India particularly in central part of the country. Madhya Pradesh has its major share in Area (70\%) and production (65\%) of soybean in India and hence knows as soybean state. In Madhya Pradesh the average productivity of soybean in very low $(11.39 \mathrm{q}$ ha-1) as compare to genetic potential (25q ha$1)$. The adoption of recommended production technology among farmers is not very encouraging. The reason may be that the most of the technology have not yet reached to the farmer's fields. Hence an efficient technology transfer system is required out of these conducts of demonstration on farmer fields have proved effective for creating awareness and acceptance of improved technologies. In this regard, to increase the productivity, the 
Department of Agriculture, Cooperation and Farmers Welfare had sanctioned the project "Cluster Frontline Demonstrations on oilseed" to ICAR-ATARI, Jabalpur through National Mission Oilseeds and Oil palm. This project was implemented by Krishi Vigyan Kendra, Dewas of Zone-IX with main objective to boost the production and productivity of Soybean crop through CFLDs with latest and specific technologies.

The FLD is an important tool for transfer of latest package of practices in totality to farmers and the main objective of this programme is to demonstrate newly released crop production and protection technologies and management practices at the farmers' field under real farming situation. Through this practice, the newly improved innovative technology having higher production potential under the specific cropping system can be popularized and simultaneously feedback from the farmers may be generated on the demonstrated technology (Singh et al., 2012).

\section{Materials and Methods}

Utilizing the information generated during Participatory Rural Appraisal (PRA), the Krishi Vigyan Kendra, Dewas conducted the field experiments of 0.40 ha each at 200 farmers fields (80 ha) of different villages of Dewas district of Madhya Pradesh viz. Dakachya, Polayjagir, Rajoda, Sukalya, Patlawada, Khatamba, Bhuriyapura, Jamgod, Mohammadpur, Bhorasa, Narana, Nanadharakhedi, Bhudhangoan, Khonpir pipliya, Dakachya, Medki dhakad, Singawada, Nipaniya, Amlawati and Bangar during the year 2016-17 and 2017-18 to evaluate the productive performance of improved varieties of Soybean. Before conducting demonstrations farmers were trained regarding different aspects of cultivation (Venkatta Kumar et al., 2010) to follow the package and practices for soybean cultivation as suggested by the scientists of Krishi Vigyan Kendra Dewas and need based input materials provided to the farmers. KVK has collected the soil sample from the demonstrations field and analyzed the sample and applied the fertilizer on the basis of soil test values. The study area receives an annual average rainfall of $1067 \mathrm{~mm}$, of which about 92.3 per cent is distributed during June to September and only 7.7 per cent between October and May. The soil of the experimental fields is black cotton with $\mathrm{pH}$ ranging from 7.0 to 7.5 .

The package of improved practices demonstrated encompassed a new variety (JS 95-60), integrated nutrient management (@ 20:60:20:20:: N:P2O5:K2O:S kg/ha + rhizobium @ 5g/kg seed + PSB @ $5 \mathrm{~g} / \mathrm{kg}$ of seed), integrated pest management (deep ploughing during April + seed treatment with Trichoderma virdae @ $5 \mathrm{~g} / \mathrm{kg}$ seed + trizophos@ $950 \mathrm{ml} / \mathrm{ha}$ ) and sowing on ridge and furrow method and Furrow irrigated raised bed method. Soybean crop was sown between 20th June to 7th July with row to row spacing of $30 \mathrm{~cm}$ using seed @ $80 \mathrm{~kg}$ per ha. An entire dose of NPK and sulphur through $\mathrm{ZnSO} 4$ was applied as basal before sowing.

Under farmers practice variety JS 9560, was planted on ridge and furrow method without any seed treatment with fungicides and biofertilizers, using higher seed rate (120- 150 $\mathrm{kg} / \mathrm{ha}$ ), broadcasting of DAP at 20 days after sowing (DAS), and following injudicious use of insecticide and weedicide.

The yield data were collected from both CFLD and farmers practice plot (local check) and compiled results. Data pertaining to crop growth, yield attributes and yield were collected at harvest and analyzed statistically. The B:C ratio was calculated based on the net return and cost of cultivation in each treatment. To estimate the technology index, 
extension gap, technology gap and harvest index, the formulae were considered as suggested by Samui et al., (2000), Kadian et al., (2004), Sagar and Chandra Ganesh, (2004).

\section{Results and Discussion}

The number of productive pods per plant of soybean (JS 95-60) ranged from 39 to 59 with a mean of 48.45 and non-productive pods per plant range from 2 to 13 with a mean of 8.16 under package of improved practices. In case of farmer's practice the respective figures recorded were 32 to 45 with a mean of 39.5 and 4.0 to 16 with a mean of 12.7 , respectively. The result revealed that the seed yield of soybean recorded was in the range of
15.29 to 18.29 qt per ha (average $16.79 \mathrm{qt} / \mathrm{ha}$ ) by adoption of improved package of practices as compared to farmers ${ }^{\text {ee }}$ practice of 12.38 to 14.68 qt per ha (average $13.53 \mathrm{qt} / \mathrm{ha}$ ). In comparison to farmers ${ }^{\text {ee }}$ practice, an increase of 14.29 to 24.59 per cent (average $19.44 \%$ ) in seed yield was recorded during the study period due to improved package of practices. Similarly, higher harvest index was recorded under improved package of practices (ranged from 47.25 to $50.41 \%$ with a mean of 48.83 $\%$ as) compared to farmers ${ }^{\text {ee }}$ practice $(45.63 \%$ to $48.48 \%$ with a mean of $47.06 \%$ ) (Table $1)$. The higher number of productive pods and higher harvest index in imparted package of practices justifies the higher yield achieved over farmer's practice.

Table.1 Grain Yield, Harvest index, Technology gap, Extension Gap and Technology index of Demonstrations

\begin{tabular}{|c|c|c|c|c|c|c|c|c|c|c|c|}
\hline \multirow[t]{2}{*}{ Year } & \multicolumn{3}{|c|}{ Grain Yield (q/ha) } & \multirow{2}{*}{$\begin{array}{c}\% \\
\text { increase } \\
\text { over FP }\end{array}$} & \multicolumn{2}{|c|}{$\begin{array}{c}\text { Straw yield } \\
\text { (q/ha) }\end{array}$} & \multicolumn{2}{|c|}{$\begin{array}{c}\text { Harvest Index } \\
(\%)\end{array}$} & \multirow[t]{2}{*}{$\begin{array}{l}\text { Technology } \\
\text { Gap (q/ha) }\end{array}$} & \multirow[t]{2}{*}{$\begin{array}{c}\text { Extension } \\
\text { Gap (q/ha) }\end{array}$} & \multirow[t]{2}{*}{$\begin{array}{l}\text { Technolog. } \\
\text { Index }(\%)\end{array}$} \\
\hline & $\begin{array}{l}\text { Potent } \\
\text { ial }\end{array}$ & $\mathrm{RP}$ & FP & & RP & FP & $\mathrm{RP}$ & FP & & & \\
\hline 1 & 2 & 3 & 4 & 5 & 6 & 7 & 8 & 9 & 10 & 11 & 12 \\
\hline 2016 & 25 & 18.29 & 14.68 & 24.59 & 18.25 & 15.60 & 50.41 & 48.48 & 6.71 & 3.61 & 26.84 \\
\hline 2017 & 25 & 15.29 & 12.38 & 14.29 & 17.07 & 14.75 & 47.25 & 45.63 & 9.71 & 2.91 & 38.84 \\
\hline Average & 25 & 16.79 & 13.53 & 19.44 & 17.66 & 15.18 & 48.83 & 47.055 & 8.21 & 3.26 & 32.84 \\
\hline
\end{tabular}

Table. 2 Gross Expenditure, Gross Return, Net Return and B:C ratio of Soybean production under CFLDs

\begin{tabular}{|c|c|c|c|c|c|c|c|c|c|c|c|}
\hline \multirow[t]{2}{*}{ Year } & \multicolumn{2}{|c|}{ Yield (q/ha) } & \multirow{2}{*}{$\begin{array}{c}\% \\
\text { increase } \\
\text { over FP }\end{array}$} & \multicolumn{2}{|c|}{$\begin{array}{c}\text { Gross Expenditure } \\
\text { (Rs/ha) }\end{array}$} & \multicolumn{2}{|c|}{$\begin{array}{l}\text { Gross Return } \\
\text { (Rs/ha) }\end{array}$} & \multicolumn{2}{|c|}{$\begin{array}{l}\text { Net Returns } \\
\text { (Rs/ha) }\end{array}$} & \multicolumn{2}{|c|}{ B:C Ratio } \\
\hline & $\mathbf{R P}$ & FP & & $\mathbf{R P}$ & FP & RP & FP & $\mathbf{R P}$ & FP & $\mathbf{R P}$ & FP \\
\hline 1 & 2 & 3 & 4 & 5 & 6 & 7 & 8 & 9 & 10 & 11 & 12 \\
\hline 2016 & 18.29 & 14.68 & 24.59 & 31000 & 30000 & 53795 & 42572 & 22795 & 12572 & 1.74 & 1.42 \\
\hline 2017 & 15.29 & 12.38 & 14.29 & 31500 & 30750 & 45870 & 37140 & 14370 & 6390 & 1.46 & 1.21 \\
\hline Average & 16.79 & 13.53 & 19.44 & 31250 & 30375 & 49833 & 39856 & 18582.5 & 9481 & 1.6 & 1.315 \\
\hline
\end{tabular}


Fig.1

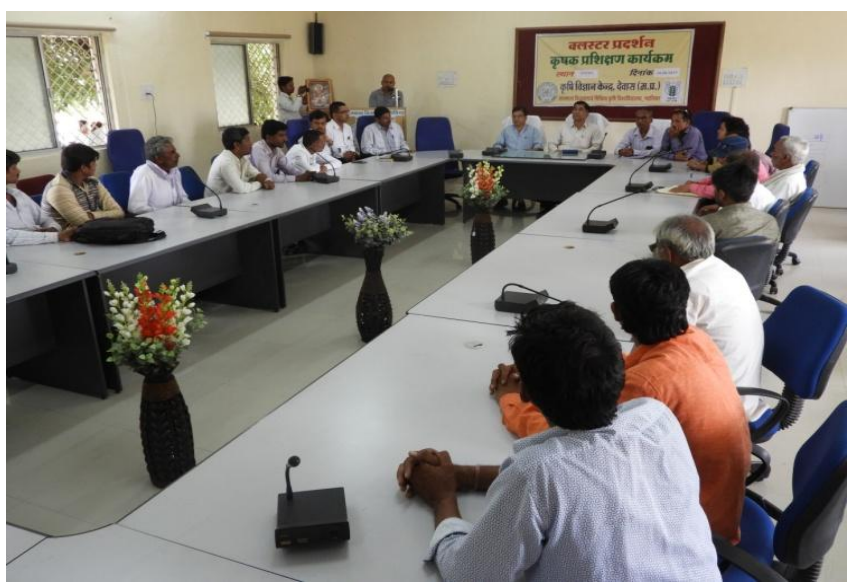

Fig.2

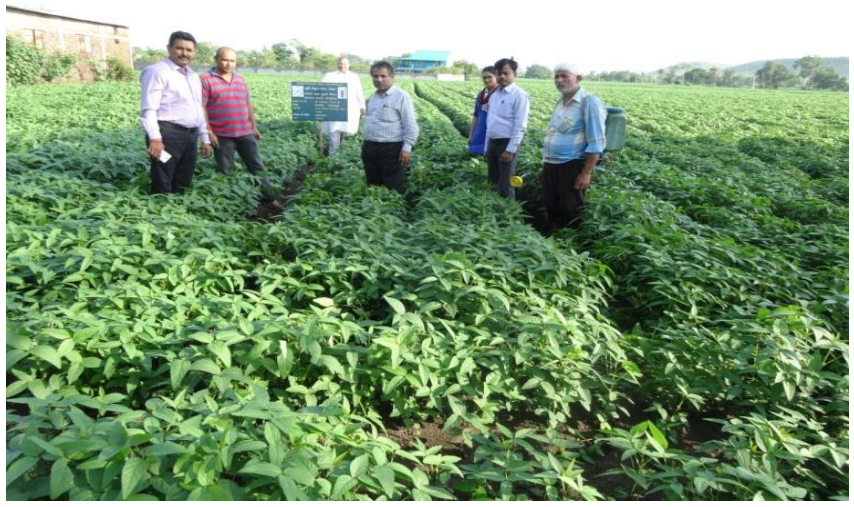

These results are in agreement with findings of Kumar et al., (2010), Jain et al., (1998) and Tiwari et al., (2013). It was also observed that the seed yield during kharif 2017 was recorded lower than that of kharif 2016 due to moisture stress during 2017 (286.9 mm less rainfall in 2017 as compare to 2016) in the district. The technological gap were found 6.71 and 9.71 qt per ha during the year 2016 and 2017, respectively with an average of $8.21 \mathrm{~kg}$ per ha (Table 1). The technology gap observed may be attributed to dissimilarity in the soil fertility status and local climatic conditions. Similarly extensions gap of 3.61 and 2.91 qt per ha were observed during 2016 and 2017, respectively. On an average the extension gap was observed $3.26 \mathrm{~kg}$ per ha, which emphasized the need to educate the farmers through various extension activities for adoption of improved agricultural production to narrow it. The technology index varied from 26.84 to 38.84 per cent with an average of 32.84 per cent during the two years of FLD program, which showed the efficacy of technical interventions. This will accelerate the adoption of technological intervention to increase the yield performance of soybean. Economic analysis (Table 2) revealed that adoption of improved package of practices required an additional cost of Rs 875 per ha over farmerse practice. This additional cost led to increased average net returns by Rs 18,583 per ha, which was higher by about 96 per cent over farmers ${ }^{\text {ee }}$ practice. The benefit cost ratios of under recommended practices were higher (1.46-1.74) than farmer's practice 
(1.21-1.42). This may be due to higher yields obtained under recommended practices compared to farmerse practices. Similar results have earlier been reported on soybean (Sharma et al., 2013; Tiwari et al., 2013) and on chickpea (Tomar et al., 1999). The result of front line demonstrations on the package of practices suggested that by its adoption, the farmers can realize higher yields and net profit in soybean cultivation. The result also indicates that the CFLD has given a good impact over the farming community of Dewas as they were motivated by the improved agricultural technologies applied in the demonstration plots.

\section{Acknowledgement}

Krishi Vigyan Kendra, Dewas is thankful to the Director, ICAR-ATARI, Zone-IX, Jabalpur and Director of Extension Services, RVSKVV, Gwalior for providing funds for conducting the CFLDs and farmers of Dewas district who always show faith in the Krishi Vigyan Kendra Dewas.

\section{References}

Jain M P and Dubey A K (1998). Productivity and economic viability of soybean with respect to planting system and cultivators in Vertisol. Crop Research 16: 102-22.

Kadian, K S., Sharma, R. and Sharma, A.K. (1997). Evaluation of front line demonstration trials on oilseeds in Kangra Vally of Himanchal Pradesh. Ann. Agric. Res.18:40.

Kumar A, Kumar R and Yadav V P S. (2010). Impact assessment of front line demonstrations of Bajra in Haryana state.
Indian Research Journal of Extension Education 12(3): 121-3.

Sagar R L and Chandra Ganesh, (2004). Front line demonstration on sesamum in west Bengal. Agricultural Extension Review 16(2): 7-10.

Samui S K, Maitra S, Roy D K, Mondal A K and Saha D, (2000). Evaluation on front line demonstration on Groundnut (Arachis hypogeal L). Journal of the Indian Society of coastal Agricultural research 18(2): 180-183.

Sharma Saurabh, Shrivastav D K, Kumar Surender and Singh Bijendra. (2013). Impact of package demonstration on soybean productivity by front line demonstration. Progressive Agriculture 13(1): 243-6.

Singh, J., Dhillon, B.S. Astha and Singh, P. (2012). Front line demonstration - An effective tool for increasing the productivity of summer Moong in Amritsar district of Punjab. An Asian Journal of Soil Science, 7(2):315-318.

Tiwari B K, Sahare K V, Sharma Ashutosh, Bain R P and Rajak A K. (2013). Impact of front line demonstration on productivity of soybean (Glycine max L. Merrill) in farmeres field. Search and Research IV(3): 32-7.

Tomar R K S (2010). Maximization of productivity for chick pea (Cicer arietinum L.) through improved technologies in farmer"es field. Indian Journal of Natural Products and Resources 1(4): 515-7.

Toamr R K S, Sharma P and Yadav L N. (1991). Comparison of yield and economics of irrigated chickpea under improved and local management practices. International Chickpea Pigeonpea News Letter 6: 22-3.

Venkattakumar, R., Ramana rao, S.V.,Padmaiah, M. And Madhuri, P. (2010). Production constraints and information needs of growers in Andhra Pradesh. Agric. Extn. Review, Apr.-June, pp. 21-24.

\section{How to cite this article:}

Bhargav, K. S., Nishith Gupta, Ankita Pandey and Dixit, A. K. 2021. Cluster Frontline Demonstrations Impact on Productivity of Soybean in Dewas District of Malwa Plateau. Int.J.Curr.Microbiol.App.Sci. 10(01): 681-685. doi: https://doi.org/10.20546/ijcmas.2021.1001.082 